\title{
Article
}

\section{HMT Exerts an Anticancer Effect by Targeting PAK-1}

\author{
Yinzhu Xu ${ }^{1,+} \mathbb{D}$, Jin-Sol Cha ${ }^{1,+}+\mathbb{D}$, Seon-Ok Lee ${ }^{1}$, Soo-In Ryu ${ }^{2}$, You-Kyung Lee ${ }^{3} \mathbb{D}$, Hengmin Han $^{3}$, \\ Jung-Eun Kim ${ }^{1}$, Min-Ho Lee ${ }^{2}$, Eun-Ok Lee ${ }^{1,3}$ and Hyo-Jeong Lee ${ }^{1,3, *(D)}$
}

1 Department of Science in Korean Medicine, College of Korean Medicine, Kyung Hee University, Hoegi-dong, Dongdaemun-gu, Seoul 02435, Korea; xyz3402@khu.ac.kr (Y.X.); cha200280@khu.ac.kr (J.-S.C.); lso4595@naver.com (S.-O.L.); kimjulie4717@khu.ac.kr (J.-E.K.); leook@khu.ac.kr (E.-O.L.)

2 Department of Food Science \& Services, Eulji University, Seongnam 13135, Kyungido, Korea; ysicute@eulji.ac.kr (S.-I.R.); minho@eulji.ac.kr (M.-H.L.)

3 Department of Cancer Preventive Material Development, College of Korean Medicine, Kyung Hee University, Hoegi-dong, Dongdaemun-gu, Seoul 02435, Korea; dbrud9575@naver.com (Y.-K.L.); helmin0730@khu.ac.kr (H.H.)

* Correspondence: strong79@khu.ac.kr

+ These authors contributed equally to this work.

check for updates

Citation: Xu, Y.; Cha, J.-S.; Lee, S.-O.; Ryu, S.-I.; Lee, Y.-K.; Han, H.; Kim, J.-E.; Lee, M.-H.; Lee, E.-O.; Lee, H.-J. HMT Exerts an Anticancer Effect by Targeting PAK-1. Appl. Sci. 2021, 11, 6034. https://doi.org/10.3390/ app11136034

Academic Editor: Domenico Osella

Received: 31 May 2021

Accepted: 27 June 2021

Published: 29 June 2021

Publisher's Note: MDPI stays neutral with regard to jurisdictional claims in published maps and institutional affiliations.

Copyright: (c) 2021 by the authors. Licensee MDPI, Basel, Switzerland. This article is an open access article distributed under the terms and conditions of the Creative Commons Attribution (CC BY) license (https:/ / creativecommons.org/licenses/by/ $4.0 /)$.

\begin{abstract}
Heamatang (HMT) is a classic medicinal formula used in traditional Chinese and Korean medicine; it contains seven distinct components, mainly of herbal origin. HMT is used as an antiaging remedy, treating urinary disorders and increasing energy and vitality. However, the therapeutic applications of this formula have not been evaluated with evidence-based science. Therefore, we assessed HMT through various in vitro methods, including cell viability assay, fluorescence-activated cell sorting assay (FACS), Western blotting, migration assay, three-dimensional (3D) cell culture, siRNA-mediated PAK-1 knockdown, and crystal violet assays. HMT decreased PAK-1 expression in PC-3 cells and inhibited cell viability, growth, and motility. The inhibition of cell motility by HMT was correlated with PAK-1-mediated inhibition of Lim domain kinase (LIMK) and cofilin. HMT induced G1 arrest and apoptosis through the transcriptional regulation of cell cycle regulatory proteins and apoptosis-related proteins (increase in c-cas3 and inhibition of PARP and BCL-2). Moreover, HMT suppressed PAK-1 expression, leading to the inhibition of AKT activities. Finally, we showed that decursin was the active ingredient involved in the inhibitory effect of HMT on PAK-1. Our findings demonstrated that HMT exerts its anticancer influence through the inhibition of PAK-1. The HMT formula could be applied in various fields, including functional health food and pharmaceutical development.
\end{abstract}

Keywords: PAK-1; prostate cancer; complementary and alternative medicine; heamatang; decursin

\section{Introduction}

Prostate cancer is the second most frequent malignancy in men worldwide. The incidence and mortality rate of prostate cancer worldwide are strongly correlated with aging (over 65 years of age) [1]. Prostate cancer manifests symptoms such as frequent urination, nocturia, hematuria, erectile dysfunction, and dysuria. Prostate cancer can spread to nearby organs, such as the bladder, or travel through the bloodstream or lymphatic system to bones and other organs [2]. Most prostate cancers require androgens for growth and are sensitive to androgen deprivation therapy (ADT). However, ADT leads to castrationresistant prostate cancer (CRPC). CRPC is advanced prostate cancer that has been known to evolve into either hormone-resistant prostate cancer (HRPC) or androgen-insensitive prostate cancer (AIPC). In this type of tumor, intracrine/paracrine androgen production plays a significant role in the insurgence of prostate cancer cells resistant to testosterone suppression therapy [3].

P21-activated kinase 1 (PAK-1), a member of the serine/threonine kinase family, plays a crucial role in tumor progression and contributes to tumor invasion and metastasis in 
various types of human cancer. PAK-1 overexpression occurs in several types of human cancer, including prostate cancer [4,5]. Moreover, PAK-1 is a major downstream effector of the Rho-family GTPase Cdc42 and Rac1 and is involved in the regulation of cell morphology and motility [6].

Cancer cell migration is a fundamental process in solid tumor formation and is required for metastasis formation [7]. The formation of cancer metastasis, which includes cancer cell migration and invasion, involves changes in cytoskeletal signaling pathways, increased motility, and enhanced cell survival. Thus, the actin cytoskeleton is an important factor in tumor cell migration and invasion [8]. It has been reported that PAKs regulate the actin cytoskeleton during cell motility and invasion [9]. The phosphorylation of both LIMK and cofilin is greatly enhanced in the presence of active PAK [10-13]. Furthermore, the expression and activity of LIMK are higher in invasive breast and prostate cancer cell lines than in less invasive lines [14]. In addition, PAK-1 plays an essential role in cell growth, adhesion, migration, and survival in colorectal cancer [15] and lung adenocarcinoma [16], through the activation of AKT, ERK, and $\beta$-catenin.

The use of complementary and alternative medicine (CAM) treatment methods, including traditional Korean medicine, has shown a steady rise among cancer patients. Many patients seek CAM therapeutic options to mitigate the side effects of chemotherapy and radiation therapy $[17,18]$. However, further studies are required to examine the efficacy and safety of CAM in anticancer therapies. Heamatang (HMT) is a traditional medicine that was described in the Compendium of Materia Medica (Bancao Gamgmu), a Chinese herbalogical and pharmaceutical textbook written by Li Shizhen during the Ming dynasty reign [19]. According to Bancao Gamgmu, HMT disperses hard masses caused by accumulation and assemblage of blood clots or waste discharge under deficient and excessive conditions over a long time. Thus, HMT could be applied to cancer treatment. However, there is a lack of scientific evidence regarding its clinical efficacy, as the therapeutic effects of this classic prescription have not been evaluated using conventional scientific methods. HMT is constituted by combining seahorse and six herbal components, namely Rheum palmatum, Pharbitidis nill Choisy, Citri unshius Markovich, Inula helnium, Croton tiglium Linne, and Angelica gigas Nakai. HMT has not been employed in modern medicine because the use of Hippocampus species was prohibited on account of the originating species being endangered. However, we were able to produce HMT in-house thanks to the farming of Hippocampus abdominalis together with its approval for use as food material in Korea. Therefore, in this study, we evaluated the impact of HMT in prostate cancer therapy using conventional scientific methods.

\section{Materials and Methods}

\subsection{Preparation of HMT}

The seven ingredients and their proportion $(w / w)$ were as follows: Hippocampus abdominalis (Seahorse Australia, Beauty Point, TAS, Australia), 16.6\%; Rheum palmatum (Donhi Herb, Seoul, Korea), 16.6\%; Pharbitidis nill Choisy (Donhi Herb, Seoul, Korea), 16.6\%; Citri unshius Markovich (Donhi Herb, Seoul, Korea), 16.6\%; Angelica gigas Nakai (Donhi Herb, Seoul, Korea), 16.6\%; Inula helnium (Donhi Herb, Seoul, Korea), 8.3\%; Croton tiglium Linne (Donhi Herb, Seoul, Korea), 8.3\%. Prof. Min-Ho Lee (Department of Food Technology and Services, Eulji University) performed botanical identification and prepared the ethanol extract. The plant name was checked with Royal Botanic Gardens, Kew Science (http://mpns.science.kew.org, accessed on 1 April 2020). The preparation method was as follows: dried and pulverized medicinal herbs were mixed and soaked in $50 \%$ ethanol $(1 \mathrm{~L} \times 3$ changes) at room temperature for three days. The extract was filtered using Whatman filter paper, evaporated (rotary evaporator, model NE-1, Japan), and lyophilized (freeze dryer, Lioalfa-6, Telstar, Terrassa, Spain) to produce $15 \mathrm{~g}$ of powder. 


\subsection{Cell Culture}

Human prostate cancer cell lines (PC-3, DU-145, and LNCaP) were purchased from American Type Culture Collection (ATCC). The cells were maintained in RPMI-1640 medium with $10 \%$ fetal bovine serum (FBS), $2 \mu \mathrm{Ml}$-glutamine, and penicillin/streptomycin (WelGene, Deagu, Korea) in a humidified atmosphere with $5 \% \mathrm{CO}_{2}$ at $37^{\circ} \mathrm{C}$.

\subsection{Cell Viability Assay}

We measured cell viability following HMT treatment in several prostate cancer cell lines using the CELLOMAX viability kit (Precaregene, Hanam, Kyungido, Korea) and the tetrazolium salt WST-8 (2-(2-methoxy-4-nitrophenyl)-3-(4-nitrophenyl)-5-(2,4-disulfophenyl)$2 \mathrm{H}$-tetrazolium, monosodium salt). Cells $\left(1 \times 10^{4}\right)$ were treated with different concentrations of $\operatorname{HMT}(0,31.3,62.5,125$, and $500 \mu \mathrm{g} / \mathrm{mL})$ in a 96-well plate for $24 \mathrm{~h}$. Then, $10 \mu \mathrm{L}$ of CELLOMAX reagent was added and incubated $2 \mathrm{~h}$ at $37^{\circ} \mathrm{C}$ in the dark. The optical density (O.D.) was measured with a microplate reader (Tecan, Sunrise, Switzerland) at $450 \mathrm{~nm}$. Cell viability was calculated using the following equation: Cell viability $(\%)=($ O.D. (FFE) - O.D. (blank))/(O.D (control) - O.D. (blank)) × 100 .

\subsection{Crystal Violet Staining Assay, Cell Growth Assay}

The crystal violet staining assay was used to determine the antiproliferative effect of HMT. PC-3 cells were seeded in a 6-well plate at a concentration of $1 \times 10^{5}$ cells $/ \mathrm{mL} /$ well and treated with different concentrations of $\operatorname{HMT}(0,50,100$, and $200 \mu \mathrm{g} / \mathrm{mL})$ for five days, with daily addition of fresh media and HMT. Then, cells were fixed with $2 \mathrm{~mL}$ of $1 \%$ glutaraldehyde solution (JUNSEI, Tokyo, Japan) in phosphate-buffered saline (PBS) for $15 \mathrm{~min}$ at $37^{\circ} \mathrm{C}$. After washing with PBS, $2 \mathrm{~mL}$ of $0.05 \%$ crystal violet (Sigma Aldrich) was added for $30 \mathrm{~min}$ to stain cells. Cells were finally washed gently with deionized water. The plates were dried at room temperature overnight. A 70\% ethanol solution was added to each well ( $2 \mathrm{~mL} /$ well) to release the crystal violet, using a rotary shaker for $2 \mathrm{~h}$ at room temperature. The O.D. was measured by a microplate reader (Tecan, Sunrise, Switzerland) at $570 \mathrm{~nm}$, with a reference filter at $405 \mathrm{~nm}$.

\subsection{Western Blot Analysis}

Cells were lysed in RIPA buffer (50 mM Tris-HCl, pH 7.4, $150 \mathrm{mM} \mathrm{NaCl}, 1 \%$ NP-40, $0.25 \%$ sodium deoxycholate, $1 \mathrm{M}$ EDTA, $1 \mathrm{mM} \mathrm{Na}_{3} \mathrm{VO}_{4}, 1 \mathrm{mM} \mathrm{NaF}$, and protease inhibitor cocktail). Protein samples were quantified using the Bio-Rad DC protein assay kit II (BioRad, Hercules, CA, USA), separated by electrophoresis on $8 \%$ to $10 \%$ SDS-PAGE gels, and transferred onto a Hybond ECL transfer membrane (Amersham Pharmacia, Piscataway, NJ, USA). The membranes were blocked in $5 \%$ nonfat skim milk and probed with primary antibodies for PAK-1 (Abcam, Cambridge, UK), phospho-AKT, AKT, LIMK1/2, phosphoLIMK1/2, cofilin, phospho-cofilin, cyclin D1, PARP, CDK4, CDK6, and cleaved caspase3 (Cell Signaling, Beverly, MA, USA) and $\beta$-actin (Sigma Aldrich Co., St. Louis, MO, USA). Membranes were exposed to horseradish peroxidase (HRP)-conjugated anti-mouse or rabbit secondary antibodies. Protein expression was examined using an enhanced chemiluminescence (ECL) system (Amersham Pharmacia, Piscataway, NJ, USA).

\subsection{Wound Healing Assay}

PC-3 cells $\left(1 \times 10^{6}\right.$ cells $\left./ \mathrm{mL}\right)$ were seeded in a 6-well plate and incubated at $37^{\circ} \mathrm{C}$. When the cells reached $50 \%$ confluence, they were scratched with a $200 \mu \mathrm{L}$ pipette tip, followed by washing with PBS. The cells were then treated with $50 \mu \mathrm{g} / \mathrm{mL}$ of HMT in a complete medium for $24 \mathrm{~h}$. After incubation, cells were fixed and stained with Diff-Quick. Randomly chosen fields were photographed under a microscope (Nikon, Tokyo, Japan). The number of cells that migrated into the scratched area was calculated. 


\subsection{Invasion Assay Using the Boyden Chamber}

PC-3 cells were treated with HMT in RPMI-1640 without FBS and were seeded in the upper chamber, containing a Matrigel-coated filter. Following this, RPMI-1640 supplemented with $10 \%$ FBS was added to the lower wells. After incubation for $24 \mathrm{~h}$, the cells on the top of the upper Matrigel-coated filter were scraped, then the invaded cells on the bottom of the inserts were fixed and stained with Diff-Quick (Sysmax). The cells on the lower surface of the filter were photographed (DFC420C, Leica, Germany) and randomly chosen fields were counted.

\subsection{Fluorescence-Activated Cell Sorting (FACS) Analysis}

PC-3 cells were treated with HMT. Then, cells were washed and fixed in $70 \%$ ethanol overnight at $-20^{\circ} \mathrm{C}$. The following day, cells were treated with RNase A $(10 \mathrm{mg} / \mathrm{mL})$ for $1 \mathrm{~h}$ at $37^{\circ} \mathrm{C}$. Then, cells were stained by adding $1 \mathrm{~mL}$ propidium iodide (PI) $(50 \mu \mathrm{g} / \mathrm{mL})$. After filtering with a nylon mesh $(40 \mu \mathrm{m})$, the DNA content of stained cells was analyzed using Cell Quest Software (BD Biosciences, San Jose, CA, USA) with a FACS Calibur flow cytometer (Becton Dickinson, Franklin Lakes, NJ, USA).

\section{9. siRNA Transfection}

The PAK-1 siRNA and control siRNA were purchased from Bioneer. To transfect the siRNAs, PC-3 cells were seeded at a density of $5 \times 10^{4}$ cells per well in a 6-well plate. Cells were transfected using $100 \mathrm{nM}$ of either the PAK-1 siRNA or the control siRNA with a siRNA transfection reagent (Polyplus) for $48 \mathrm{~h}$. After treatment, cells were stimulated with HMT and then analyzed with Western blotting assay and stained with crystal violet. The O.D. was measured by a microplate reader (Tecan, Sunrise, Switzerland) at $570 \mathrm{~nm}$, with a reference filter at $405 \mathrm{~nm}$.

\subsection{D Culture Tumor Organoids}

For the generation of the PC-3 tumor organoids, cells were seeded into 96-well roundbottom ultra-low-attachment plates (Corning) at 2000 viable cells per well. The PC-3 spheroids were grown in RPMI medium with $10 \%$ FBS. The plates were incubated for 5 days at $37^{\circ} \mathrm{C}$, during which they formed spheroids. Then, the spheroids were treated with $200 \mu \mathrm{g} / \mathrm{mL}$ HMT for $48 \mathrm{~h}$. For the apoptosis analysis, $2 \mu \mathrm{M}$ CellEvent (Invitrogen, Waltham, MA, USA) was added to each well for $1 \mathrm{~h}$. Pictures were obtained using a fluorescence microscope (Nikon, Tokyo, Japan). The fluorescence intensity of caspase-3/7 was evaluated using the ImageJ software. For the calculation of fluorescence intensity with ImageJ, two images of each well were analyzed, and their average intensity was used for the statistical analysis.

\subsection{TLC and HPLC Analysis}

Decursin standard and HMT were spotted on Silica gel 60 thin-layer plates (Merck, Darmstadt, Germany). After development in isopropyl alcohol/ethyl acetate/water (3/1/1, $v / v / v)$, the TLC plate was dried and visualized by dipping in a solution containing $0.3 \%$ $(w / v) \mathrm{N}-\left(1\right.$-naphthyl)-ethylenediamine and $5 \%(v / v) \mathrm{H}_{2} \mathrm{SO}_{4}$ in methanol and was heated at $110^{\circ} \mathrm{C}$ for $10 \mathrm{~min}$. We then performed high-performance liquid chromatography (HPLC) on a Luna C18(2) $100 \AA ̊$ reverse phase column $(250 \mathrm{~mm} \times 4.6 \mathrm{~mm}, 5 \mu \mathrm{m}$, Phenomenex, Inc., Seoul, Korea) connected to an Agilent Technologies 1100 series system, with a detector at $329 \mathrm{~nm}$ at $30{ }^{\circ} \mathrm{C}$ and using a mobile phase of $100 \%$ ethanol $/ 0.1 \%$ formic acid in water $(7 / 3$, $v / v)$ under isocratic mode with a flow rate of $1 \mathrm{~mL} / \mathrm{min}$. The chromatography peak was identified by comparing the retention time of the sample with the reference standard. 


\section{Results}

\subsection{HMT Suppresses PAK-1}

The PC-3 line has a high metastatic potential among prostate cancer cell lines. We thus tested whether HMT treatment could reduce PAK-1 expression in PC-3 cells by Western blotting assay. Indeed, HMT inhibited the PAK-1 protein level in PC-3 cells (Figure 1A).

A.

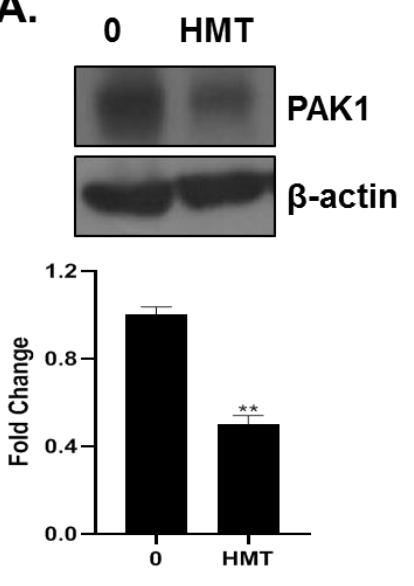

B.

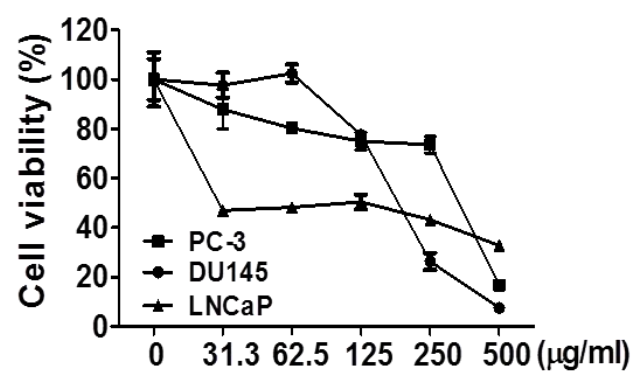

C.
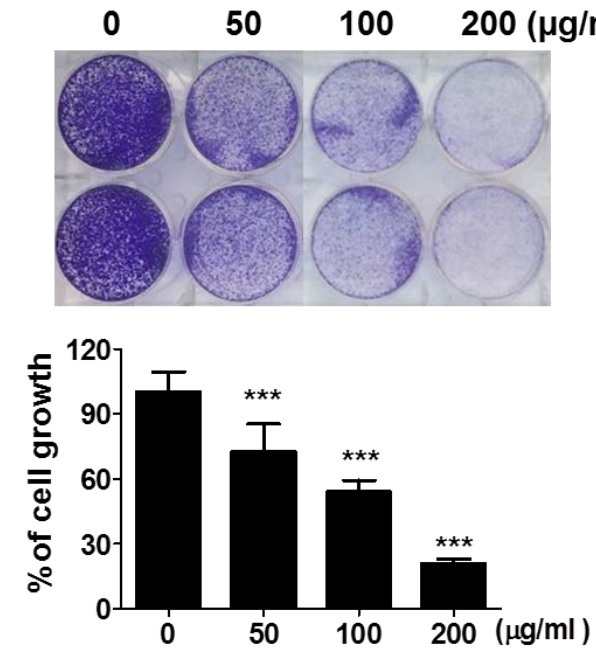

Figure 1. The inhibitory effect of HMT on PAK-1 expression and cell growth in PC-3 cells. (A) HMTtreated PC-3 cell lysates were prepared and subjected to Western blotting for PAK-1 expression. Densitometric analysis was used to evaluate the ratio of protein of interest to $\beta$-actin, and results are presented as fold change of the control. Data represent mean \pm SD. ${ }^{* *} p<0.01$ compared with control. (B) Cells (LNCaP, DU-145, and PC-3 cells) were treated with various concentrations of HMT for $24 \mathrm{~h}$, and cell viability was measured by using CELLOMAX viability kit. Data represent mean \pm SD. (C) The antiproliferation activity, cell growth, for long-term treatment of HMT was carried out by cell growth crystal violet assay. PC-3 cells were treated with HMT (50, 100, and $200 \mu \mathrm{g} / \mathrm{mL}$ ) for 4 days. The cells were stained with crystal violet and were photographed and resolved in $70 \% \mathrm{EtOH}$, and the absorbance was measured using a microplate reader. Data represent mean $\pm \mathrm{SD}$. ${ }^{*} p<0.05$, ** $p<0.01$, and ${ }^{* * *} p<0.001$ compared with control.

\subsection{HMT Inhibits Cell Growth}

We then examined the cytotoxic effect of HMT in several prostate cancer cell lines. We performed a cell viability assay $24 \mathrm{~h}$ after HMT treatment in the PC-3, DU-145, and LNCaP lines. As shown in Figure 1B, HMT treatment reduced cell viability in PC-3, DU-145, and LNCaP cells in a dose-dependent manner. The treatment with $31.3 \mu \mathrm{g} / \mathrm{mL}$ HMT reduced prostate cancer viability by $12.2 \%$ (PC-3), $13.5 \%$ (DU-145), and $53.9 \%$ (LNCaP). LNCaP cells were the most sensitive to HMT (Figure 1B). 
We then performed a cell growth assay to assess the impact of HMT treatment in the long-term (4d) growth of prostate cancer cells. As shown in Figure 1C, HMT significantly suppressed cell growth in a dose-dependent manner. HMT suppressed cell growth, decreasing cell growth by $28 \%, 46 \%$, and $79 \%$ at 50,100 , and $200 \mu \mathrm{g} / \mathrm{mL}$ of HMT, respectively (Figure 1C).

\subsection{HMT Inhibits Cell Migration and Invasion by Inhibiting PAK-1 Pathway}

To investigate whether HMT could suppress prostate cancer cell motility without exhibiting cell toxicity, we used a wound-healing and Matrigel-coated membrane invasion assay. As shown in Figure 2A,B, in the Matrigel-coated invasion assay, HMT inhibited cell invasion by $50 \%$ compared to the untreated control. Moreover, in the wound healing assay, HMT treatment decreased serum-induced cell migration by $57 \%$ compared to the untreated control. As shown in Figure 1B, the inhibitory effect of cell motility by HMT was not linked to cell toxicity. Notably, $62.5 \mu \mathrm{g} / \mathrm{mL}$ HMT suppressed cell viability by $15 \%$ in the PC-3 cell lines compared to the control (Figure 1B). To confirm that the inhibitory effect of HMT in cancer cell migration and invasion was correlated to PAK-1 regulation, we performed Western blotting to measure the protein levels changes of PAK-1 and PAK-1-regulated cell motility proteins following HMT treatment in PC-3 cells. A concentration of $50 \mu \mathrm{g} / \mathrm{mL}$ HMT attenuated PAK-1, AKT, LIMK, and cofilin protein levels (Figure 2C).

\subsection{HMT Induces G1 and Sub-G1 Arrest}

To evaluate whether HMT can modulate cell cycle progression, cell cycle analysis was performed by treating PC-3 cells with high concentrations of $\operatorname{HMT}(10,200$, and $400 \mu \mathrm{g} / \mathrm{mL})$ for $24 \mathrm{~h}$. As shown in Figure 3A, HMT gradually increased G1 and sub-G1 durations in a dose-dependent manner compared to those in the nontreated cells. Particularly, the increase in sub-G1 arrested cells treated with $400 \mu \mathrm{g} / \mathrm{mL}$ HMT was 76\% (Figure 3A).

A.

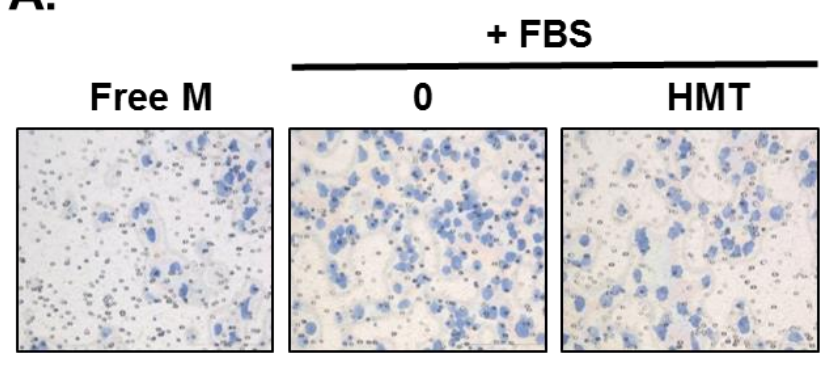

B.
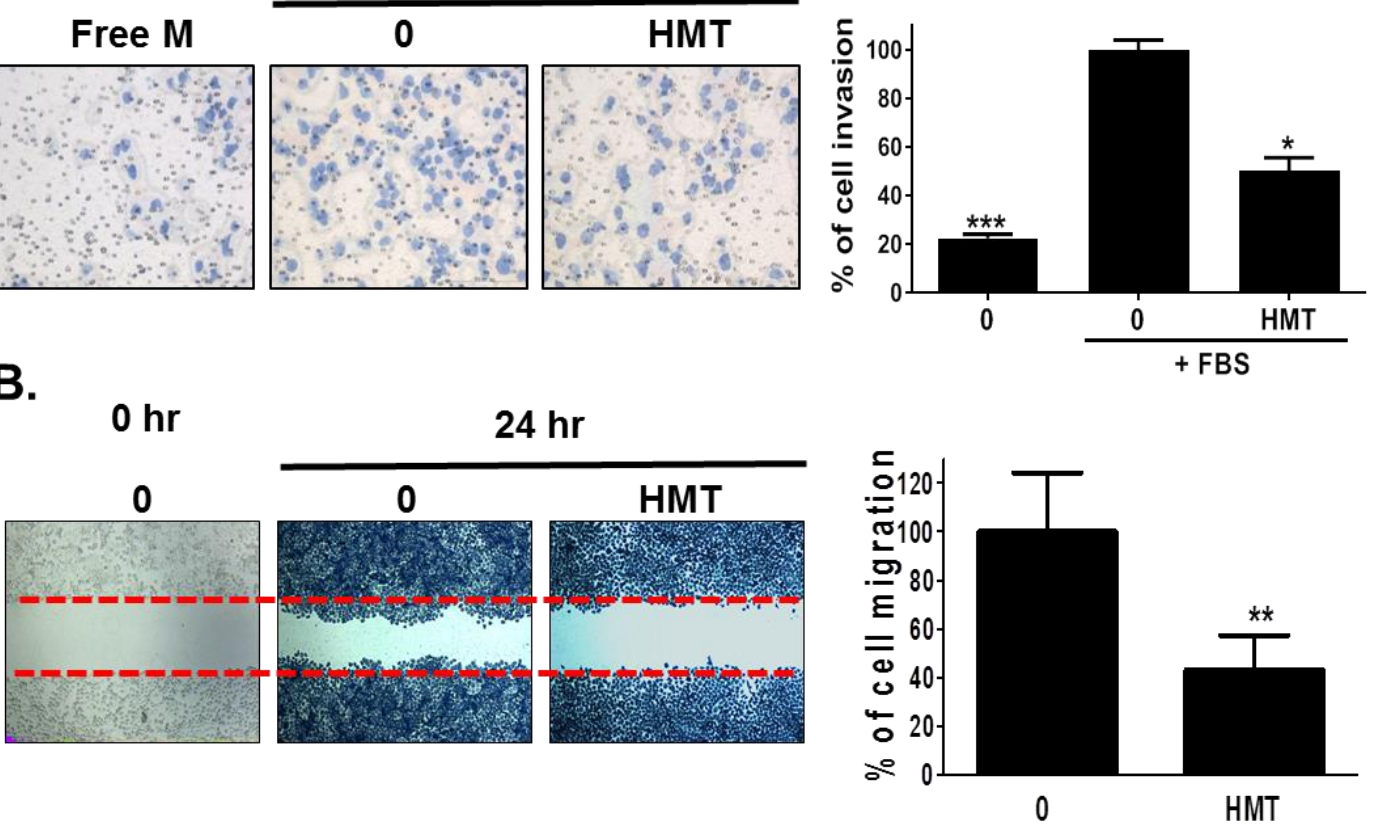

Figure 2. Cont. 

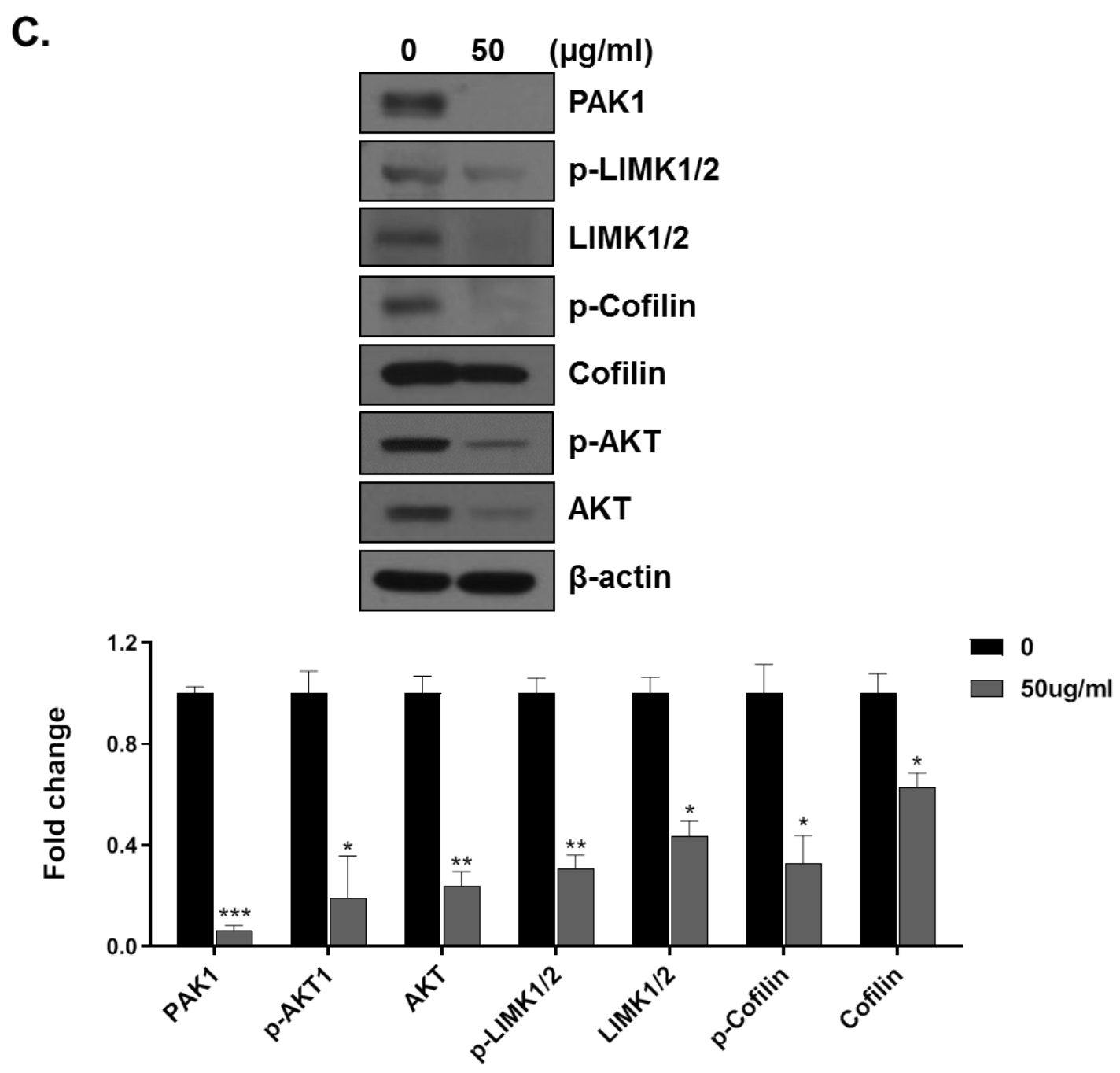

Figure 2. Inhibitory effect of HMT on cell migration and invasion in PC-3 cells. Cells were treated with HMT (50 $\mu \mathrm{g} / \mathrm{mL})$ for $24 \mathrm{~h}$. (A) The cells invading into the Matrigel-coated membrane were photographed (X100), and the number of invasive cells was calculated as a percentage of invasion. (B) The cells migrating into the scratched area were photographed (X100), and the number of migratory cells was calculated as a percentage of migration. (C) HMT-treated PC-3 cell lysates were prepared and subjected to Western blotting for cell motility-related proteins in the PAK-1 signaling pathway (PAK-1, LIMK1/2, p-LIMK1/2, cofilin, p-cofilin, AKT, p-AKT, and $\beta$-actin). The bar graph indicates the ratio of the protein of interest to $\beta$-actin by densitometric analysis presented as fold changes of the control. Data represent mean $\pm \mathrm{SD} .{ }^{*} p<0.05,{ }^{* *} p<0.01$, and ${ }^{* * *}$ $p<0.001$ compared with control.

To confirm the presence of HMT-mediated apoptotic cells, we stained PC-3 cells treated with $200 \mu \mathrm{g} / \mathrm{mL}$ HMT for $24 \mathrm{~h}$ with the CellEvent Caspase-3/7 detection dye. As shown in Figure 3C, we detected no cas3/7 fluorescent cells in the control group. On the other hand, HMT-treated cells showed green fluorescence in almost all cells.

We next assessed whether HMT-mediated G1 and sub-G1 arrest (apoptosis) were dependent on changes in G1-regulating and apoptotic-related proteins. HMT treatment decreased the levels of G1-regulating proteins (CDK6) and increased apoptosis through the inhibition of BCL-2 and PARP and the increase of cleaved caspase-3 (Figure 3D). The apoptosis pathways activate the programmed cell death through the mitochondria, which are involved in the regulation of apoptosis [20]. The chemical-induced apoptotic pathway involving mitochondria is regulated by apoptosis-related key proteins such as $\mathrm{BCl}-2 / \mathrm{Bax}$ and cytochrome $\mathrm{C}$, with subsequent activation of caspase-3 and PARP [20-23]; BCl-2, caspase-3, and PARP are representative markers of apoptosis. 
A.

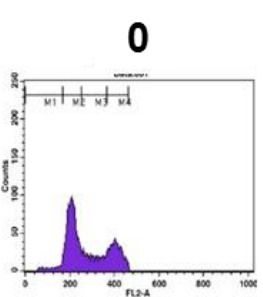

$100(\mu \mathrm{g} / \mathrm{ml})$

B.
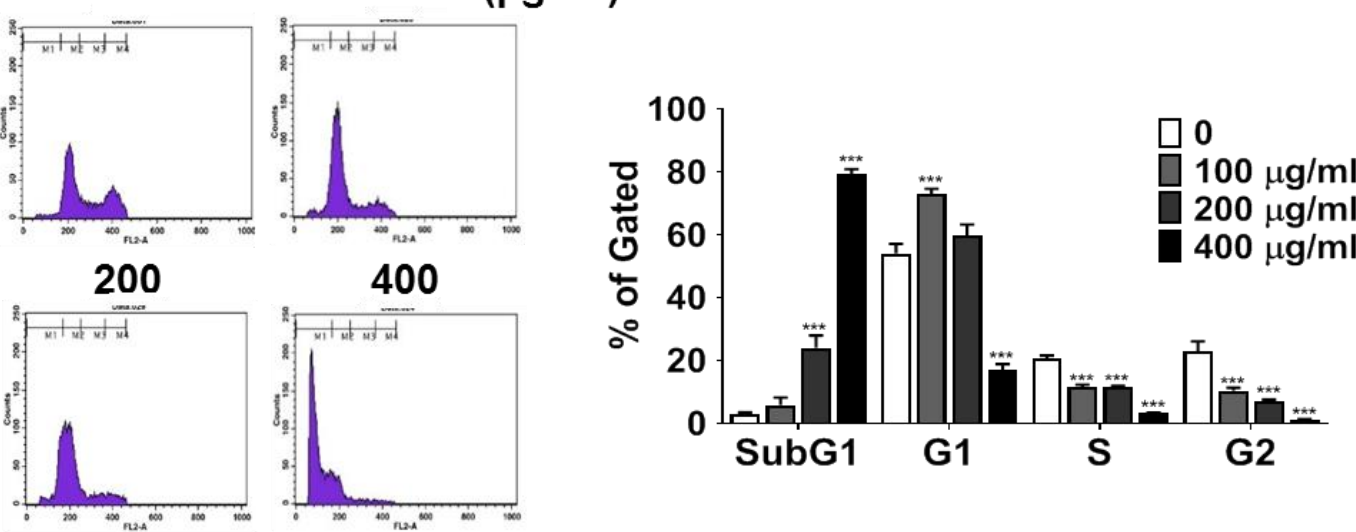

C.
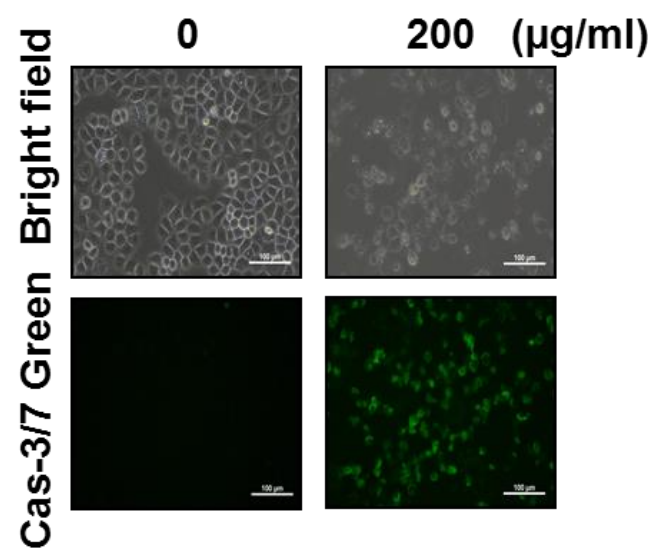

D.

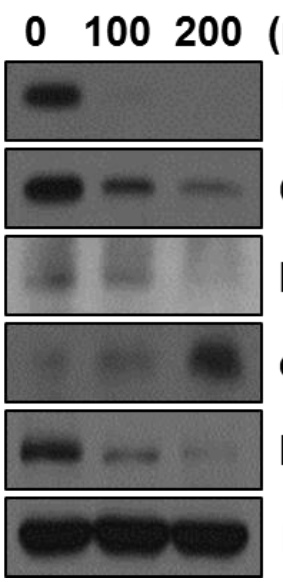

$(\mu \mathrm{g} / \mathrm{ml})$

PAK1

(1)

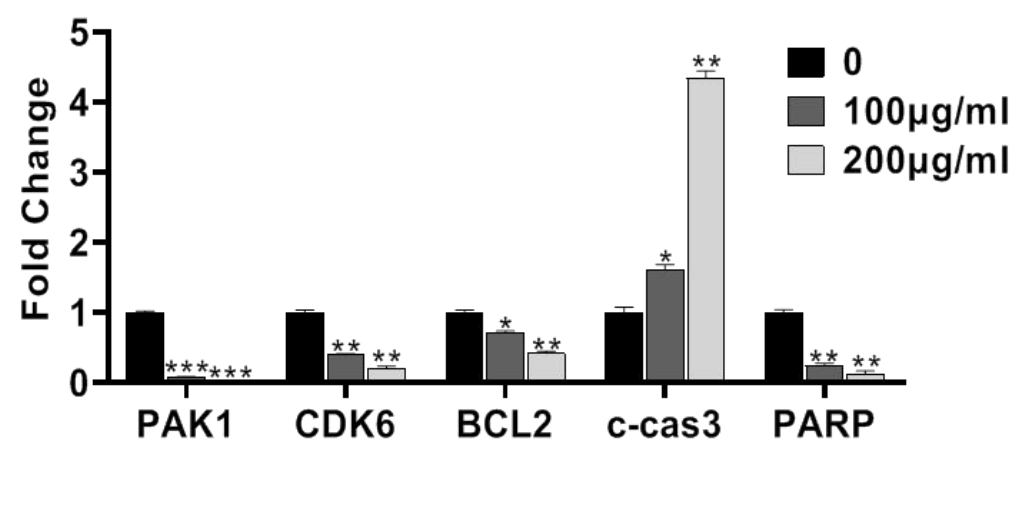

Figure 3. Effect of HMT on cell cycle arrest and apoptosis in PC-3 cells. PC-3 cells were treated with HMT (100, 200, and $400 \mu \mathrm{g} / \mathrm{mL}$ ) for $24 \mathrm{~h}$. (A) The treated cells were stained with propidium iodide (PI) and analyzed by flow cytometry. (B) Bar graphs show the quantification of the cell cycle population (\%). Data represent mean $\pm \mathrm{SD}$. ${ }^{*} p<0.05,{ }^{* *} p<0.01$, and ${ }^{* * *} p<0.001$ compared with control. (C) PC-3 cells were treated with HMT $(200 \mu \mathrm{g} / \mathrm{mL})$ for $24 \mathrm{~h}$ and stained with $2 \mu \mathrm{M}$ CellEvent for apoptosis analysis and imaged using a fluorescence microscope $(200 \times)$ (Nikon, Tokyo, Japan). (D) HMT (100 and $200 \mu \mathrm{g} / \mathrm{mL}$ )-treated PC-3 cell lysates were prepared and subjected to Western blotting for cell cycle- and apoptosisrelated proteins (PAK-1, CDK6, BCL-2, cleaved caspase-3, PARP, and $\beta$-actin). Band density of proteins was quantified using the Gelpro analyzer (Media Cybernetic, Bethesda, MD, USA). The bar graph indicates the ratio of the protein of interest to $\beta$-actin by densitometric analysis presented as fold changes of the control. Data represent mean $\pm \mathrm{SD}$. ${ }^{*} p<0.05$, ** $p<0.01$, and *** $p<0.001$ compared with control. 
3.5. PAK-1 Mediates HMT-Induced G1 Arrest and Apoptosis and Suppresses Cell Proliferation and Cell Motility

Next, we assessed whether the anticancer effect of HMT is dependent on PAK-1. Upon knockdown of PAK-1 by siRNA, we observed a reduction in the expression of the G1regulatory protein cyclin D1 and the induction of the apoptotic protein cleaved caspase-3 (Figure 4A). Moreover, the PAK-1 knockdown attenuated the expression of LIMK1/2 and cofilin. The expression profile of PAK-1-knockdown cells was similar to that observed in HMT-treated cells (Figure 4A). Moreover, PAK-1 knockdown enhanced HMT-mediated inhibition of cell growth (Figure 4B). In addition, HMT treatment significantly suppressed PAK-1 expression in two prostate cancer cell lines, LNCaP and DU145 (Figure 4C).

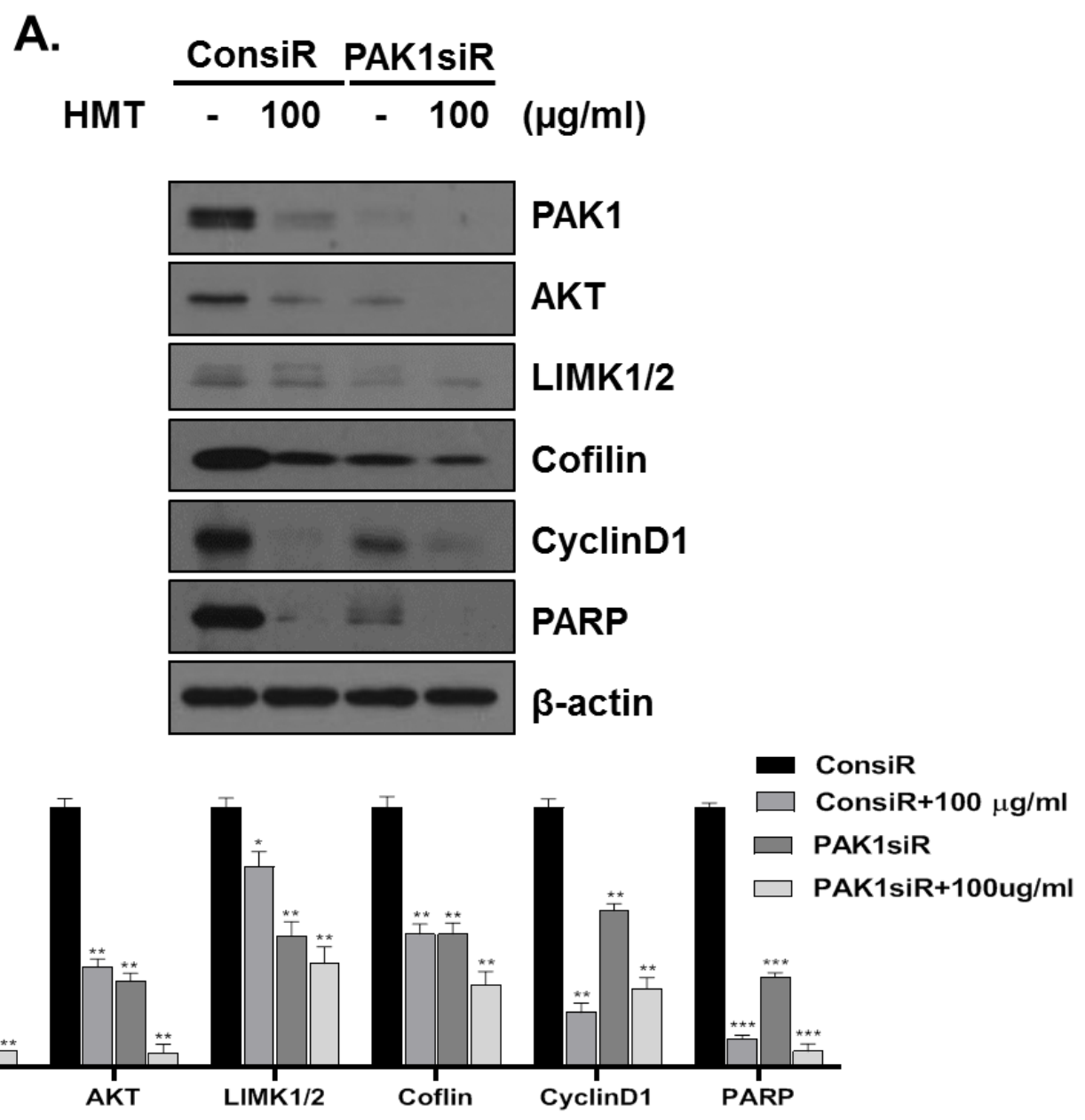

Figure 4. Cont. 
B.

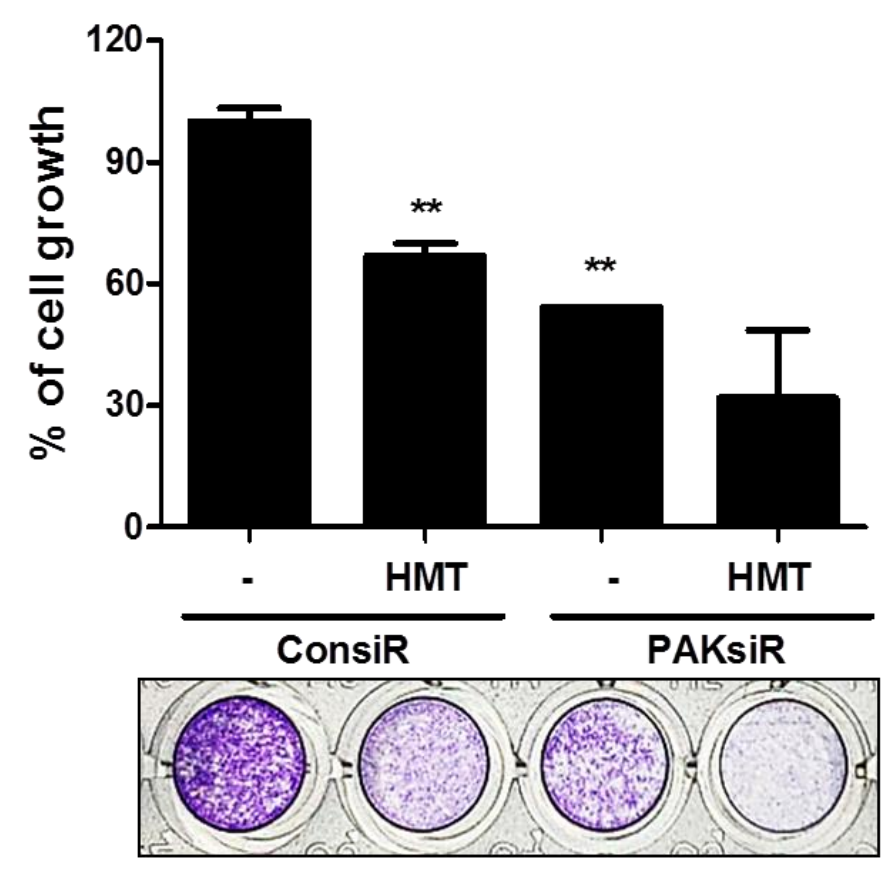

C.
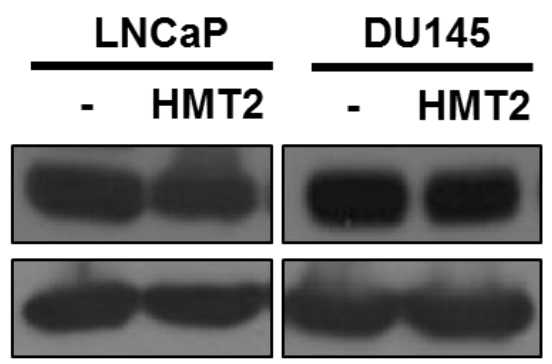

PAK1

$\beta$-actin

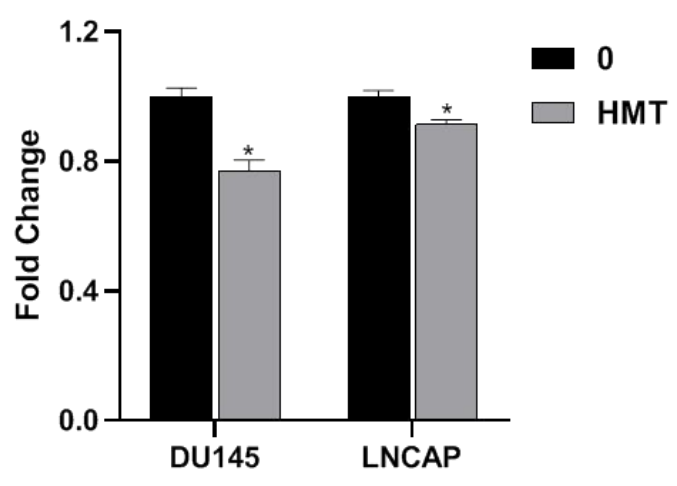

Figure 4. Effect of PAK-1 siRNA on cell migration, proliferation, and apoptosis-related markers in HMT treated PC-3 cells. PC-3 cell lysates treated with PAK-1 siRNA and HMT were prepared and subjected to Western blotting (A) with antibodies against PAK-1, AKT, LIMK1/2, cofilin, cyclin D1, c-cas3, and $\beta$-actin. The bar graph indicates the ratio of the protein of interest to $\beta$-actin by densitometric analysis presented as fold changes of the control. Data represent mean \pm SD. ${ }^{*} p<0.05$, ${ }^{* *} p<0.01$, and ${ }^{* * *} p<0.001$ compared with control. (B) The cell growth was assayed by crystal violet staining. The stained cells were photographed and resolved in $70 \% \mathrm{EtOH}$, and the absorbance was measured using a microplate reader. Data represent mean \pm SD. ${ }^{*} p<0.05,{ }^{* *} p<0.01$, and ${ }^{* * *} p<0.001$ compared with control. (C) HMT-treated PAK-1 expression in LNCaP and DU145 cells by Western blotting. The bar graph indicates the ratio of the protein of interest to $\beta$-actin by densitometric analysis presented as fold changes of the control. Data represent mean \pm SD. ${ }^{*} p<0.05$ compared with control.

\subsection{HMT Reduces Tumor Spheroid Viability}

We used the PC-3 tumor spheroid model further to assess the effect of HMT treatment on tumor growth. This three-dimensional culture model mimics some aspects of the in vivo tumor organization and is better suited to study the response of cancer cells to a drug. As shown in Figure 5A, the cell viability of the PC-3 spheroids, as measured by WST-8, was reduced by $41 \%$ following the addition of $200 \mu \mathrm{g} / \mathrm{mL}$ of HMT, similarly to what was observed in 2D cultures (Figure 4A). To measure the effect of HMT on apoptosis in the 3D PC-3 cells model, we used CellEvent, a fluorogenic Caspase-3/7 substrate: following HMT treatment, we readily detected apoptosis also in this model (Figure 5B). 


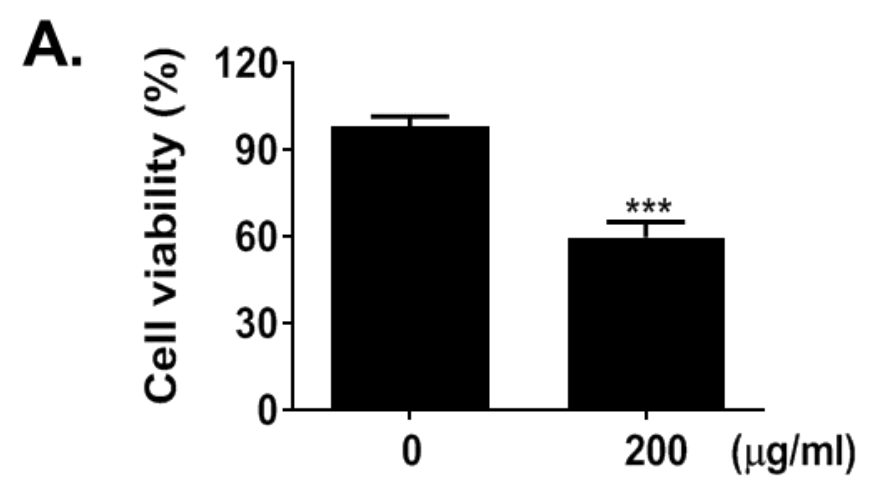

B.

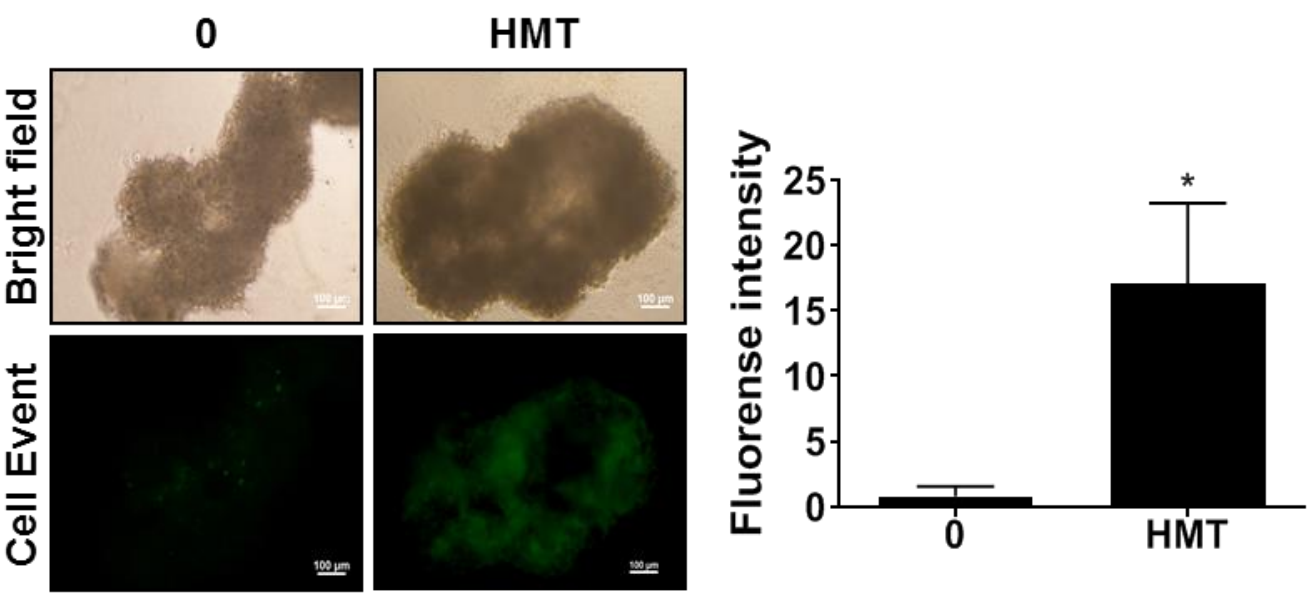

Figure 5. Inhibitory effect of HMT on 3D culture PC-3 tumor organoid growth. Five days after spheroid formation, the formed spheroids were treated with $200 \mu \mathrm{g} / \mathrm{mL}$ HMT for $48 \mathrm{~h}$. Six organoids per group were used. (A) For organoid viability, the CELLOMAX viability kit was added to each well and reacted for $18 \mathrm{~h}$. Data represent mean \pm SD. ${ }^{*} p<0.05$, ${ }^{* *} p<0.01$, and ${ }^{* * *} p<0.001$ compared with control. (B) For apoptosis analysis, $2 \mu \mathrm{M}$ CellEvent (Invitrogen, USA) was added to each well and reacted for $1 \mathrm{~h}$. Pictures were obtained using a fluorescence microscope (Nikon, Tokyo, Japan).

\subsection{HMT Contains Decursin That Inhibits PAK-1}

To identify the active compounds in HMT correlated to the anticancer activity, we determined the presence in HMT of the main herbal compounds (naringin, decursin, catechin, gallic acid, and epicatechin) using TLC (data not shown). This preliminary TLC analysis $(254 \mathrm{~nm}$ ) revealed the presence of decursin, as shown in Figure 6A.

We then performed HPLC analysis to calculate the retention time of decursin $(5.014 \mathrm{~min})$ and estimated its abundance in the HMT preparation $(23.05 \mathrm{mg} / \mathrm{g})$ (Figure $6 \mathrm{~B})$. We then evaluated the effect of pure decursin on -1 expression. At a concentration of $10 \mu \mathrm{M}$, decursin significantly suppressed PAK-1 expression (Figure 6C). 
A.

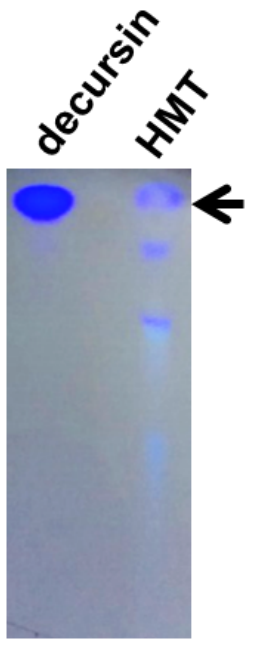

B.
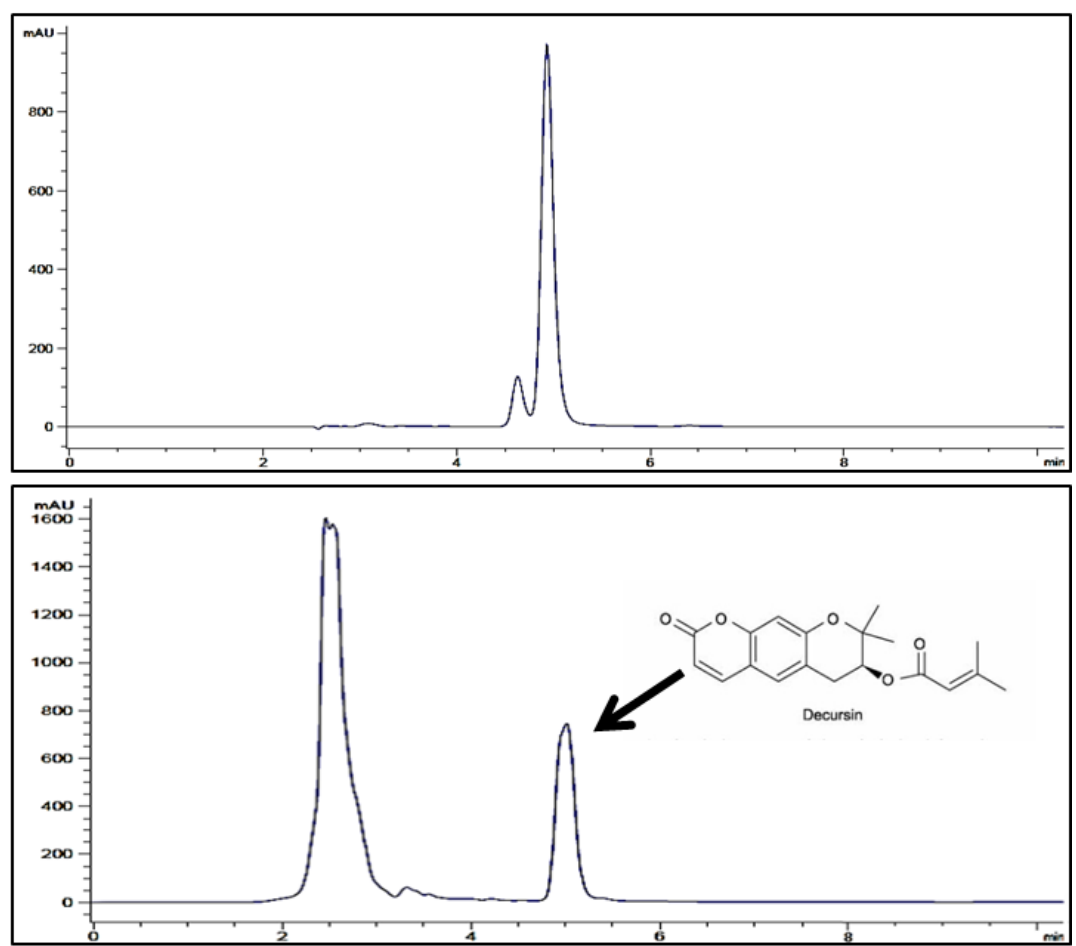

C.

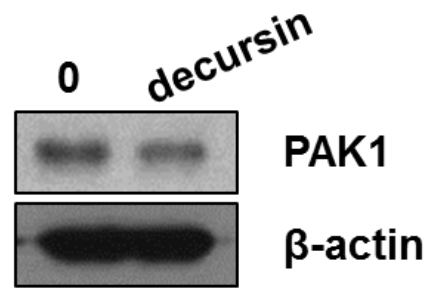

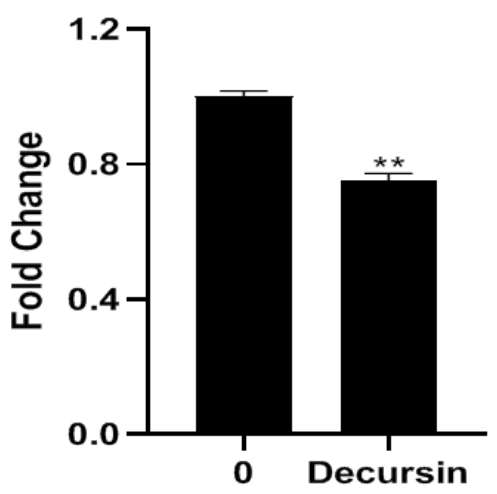

Figure 6. HMT contains decursin that inhibits PAK-1. (A) TLC analyses of HMT. For the detection of decursin, the TLC plate was dipped in 10\% sulfuric acid to char carbon-containing compounds. (B) HPLC profile. Upper section: standard of decursin, lower section: HMT. (C) Changes in PAK-1 expression in response to decursin in PC-3 cells. Cells were treated with decursin (at $10 \mu \mathrm{M})$ for $24 \mathrm{~h}$. Cell lysates were prepared and subjected to Western blotting using PAK-1 antibodies. The bar graph indicates the ratio of the protein of interest to $\beta$-actin by densitometric analysis presented as fold changes of the control. Data represent mean \pm SD. ${ }^{* *} p<0.01$ compared with control.

\section{Discussion}

Since PAKs were discovered in 1994, several studies demonstrated their crucial roles in numerous cellular processes, such as cell cycle progression and cell survival [24]. PAK-1 belongs to the Group I of the PAK family and was identified for the first time in a screening for proteins that interacted with GTP-bound Rac [25]. PAK-1 is overexpressed in a variety of cancers, including prostate cancer [26]. PAK-1 was recently shown to be a valid therapeutic target for cancer treatment [27]. Since then, several PAK-1 inhibitors have been developed for use as biological markers and therapeutic agents [28].

Recent studies investigating the antitumor effect of natural products suggested that they may lead to promising alternative therapy for the treatment of cancer. Traditional Chinese or Korean medicine is widely accepted as an alternative treatment for cancer [29-31]. 
Furthermore, research on traditional Chinese and Korean medicinal and herbal formulations has been recognized internationally by medical researchers [32], and several studies elucidated the molecular and cellular mechanisms of herbal medicine-derived phytochemicals in the context of cancer research [33-35]. In this study, we investigated the effect of oriental medicinal herbs on PAK-1 signaling. Previously, we reported the effect of PAK-1 inhibitor EOPK (essential oil of Pinus koraiensis) in HCT 116 cells [36]. Now, we have identified a second PAK-1 inhibitor isolated from HMT.

Recent studies have shown that there are several possible links between PAK and PI3K and Raf-MAPK pathways [5,36-38]. To confirm the involvement of PAK-1 in the HMT-mediated anticancer effect, we evaluated expression changes of proteins involved in the PAK-1 pathway by knocking down PAK-1 with siRNA. As shown in Figure 4, knockdown of PAK-1 by siRNA reduced the expression of the G1-regulatory protein cyclin D1, LIMK1/2, and cofilin and induced expression of the apoptotic protein cleaved caspase-3. Furthermore, this knockdown enhanced the HMT-mediated anticancer effects by inhibiting the PAK-1/AKT pathway. Consistently with our data, PAK-1 inhibition using shRNA or siRNA strategies induced apoptosis and CDK4/6 inhibition [39-41].

HMT is mainly prepared using extracts from Hippocampus abdominalis, Angelica gigas Nakai, Rhem palmatum, and Critri unshius Markovich. The Hippocampus extract contains steroids and fatty acids and possesses various pharmacological properties including antitumor effects [42,43] and anti-prostatic hyperplasia activity [44,45]. Rhem palmatum contains emodin, which has been reported to target the AR directly and induce apoptosis [46,47]. Moreover, emodin has been reported to inhibit tumor cell migration through suppression of the PI3-K-cdc42/Rac1 pathway in MDA-MB-231 cells [48]. Rhem palmatum contains catechin and epicatechin. Green tea catechins have been reported to possess anticancer effects by many researchers [49-52]. The therapeutic mechanisms of catechins, especially in prostate cancer, include direct action on cancer cells and indirect action on tumor-associated inflammation [53]. Critri unshius Markovich contains hesperidin and naringin. According to a recent study, naringin inhibits cell viability and induces apoptosis in PC-3, LNCaP, and DU145 cells. Furthermore, naringin synergistically increases the effect of paclitaxel in the treatment of prostate cancer cells [54]. Korean Angelica gigas Nakai is a major medicinal herb. Traditionally, its dried root has been used to treat anemia, pain, infection, and articular rheumatism in Korea, most often by boiling the roots in water. TLC and HPLC data show that HMT contains large amounts of decursin (2\% in HMT) (Figure 6A,B). Decursin could be a representative ingredient in HMT. Decursin is a major chemical component of Angelica gigas extract and has been previously associated with antitumor effects in prostate cancer [55-58]. Moreover, decursin decreases cell proliferation and angiogenesis and increases apoptosis in vitro and in PC-3 and DU-145 xenograft models [57,59]. By using TLC, we did not find the presence of other compounds (naringin, emodin, catechin, gallic acid, and epicatechin). However, further analyses are necessary to identify the presence of other compounds, since the anticancer activity of these components may contribute to the total HMT antitumor activity.

Three-dimensional (3D) growth of immortalized cell lines or primary cells is regarded as a more physiological model to perform in vitro screening, as 3D cell cultures possess several in vivo features of tumor organization $[60,61]$. We evaluated the anticancer effect of HMT in a 3D culture growth model. As shown in Figure 5B, the PC-3 tumor organoids were bumpy, not showing the typically spheroid and uniform morphology. Thus, the PC-3 line has high metastatic potential among prostate cancer cell lines. PC-3 cells lack cellcell adhesion molecules that are related to cell motility, migration, and invasion, making spheroid tumor formation difficult in the absence of a synthetic matrix, such as ECM (extracellular matrix) components. In other words, cancer cells with low expression of cell adhesion molecules, such as E-cadherin, can have increased metastatic potential due to enhanced cell motility. Moreover, previous studies reported that PC-3 cells have no or low levels of E-cadherin and alpha-catenin [62]. As shown in Figure 5A, the organoids of the control group were brighter than those of the HMT-treated group in bright field pictures. 
On the other hand, the spheroids of the HMT-treated group were darker than those of the control group in the whole area. Consistently, the CellEvent-positive spheroids showed a dark section, consistent with apoptosis induction [63-65].

\section{Conclusions}

In summary, we demonstrated that, in PC-3 cells, a nontoxic dose of HMT decreased cell migration; cell invasion; and the expression of PAK-1, AKT, LIMK1/2, and cofilin. HMT reduces cell proliferation by arresting cells in the G1 phase, through the reduction in CDK4/6 and cyclin D1 expression levels. HMT also induces apoptosis through sub-G1 arrest by decreasing PARP and BCL-2 expression levels and inducing the expression of cleaved caspase-3. Interestingly, HMT treatment and PAK-1 knockdown by siRNA showed a similar phenotype in PC-3 cells. Moreover, we identified that decursin, a component of HMT, was an inhibitor of PAK-1. Our findings demonstrated that HMT inhibits cell motility and growth and induces apoptosis by inhibiting the PAK-1/AKT and the PAK1/LIMK1/2/cofilin signaling pathway. Collectively, these data suggest that HMT could be used as a starting point for the development of functional health foods and medicine.

Author Contributions: H.-J.L. conceived and designed experiments and revised the manuscript; Y.X. and J.-S.C. performed the experiments. S.-O.L., Y.-K.L., H.H., J.-E.K. and E.-O.L. analyzed the data. M.-H.L. prepared and provided the HMT. S.-I.R. performed TLC and HPLC analysis. All authors have read and agreed to the published version of the manuscript.

Funding: This work was supported by Basic Science Research of the National Research Foundation of Korea (NRF) and funded by the Ministry of Science, ICT, and Future Planning Program (NRF2018R1D1A1B07049449).

Conflicts of Interest: We declare that the research was conducted in the absence of any commercial or financial relationship that could be construed as a potential conflict of interest.

\section{References}

1. Rawla, P. Epidemiology of Prostate Cancer. World J. Oncol. 2019, 10, 63-89. [CrossRef] [PubMed]

2. Available online: https://www.mayoclinic.org/diseases-conditions/prostate-cancer/symptoms-causes/syc-20353087 (accessed on 28 February 2020).

3. Mostaghel, E.A.; Page, S.T.; Lin, D.W.; Fazli, L.; Coleman, I.M.; True, L.D.; Knudsen, B.; Hess, D.L.; Nelson, C.C.; Matsumoto, A.M.; et al. Intraprostatic androgens and androgen-regulated gene expression persist after testosterone suppression: Therapeutic implications for castration-resistant prostate cancer. Cancer Res. 2007, 67, 5033-5041. [CrossRef] [PubMed]

4. Carter, J.H.; Douglass, L.E.; Deddens, J.A.; Colligan, B.M.; Bhatt, T.R.; Pemberton, J.O.; Konicek, S.; Hom, J.; Marshall, M.; Graff, J.R. Pak-1 expression increases with progression of colorectal carcinomas to metastasis. Clin. Cancer Res. 2004, 10, $3448-3456$. [CrossRef] [PubMed]

5. Wang, Z.; Jia, G.; Li, Y.; Liu, J.; Luo, J.; Zhang, J.; Xu, G.; Chen, G. Clinicopathological signature of p21-activated kinase 1 in prostate cancer and its regulation of proliferation and autophagy via the mTOR signaling pathway. Oncotarget 2017, 8, 22563-22580. [CrossRef]

6. Manser, E.; Leung, T.; Salihuddin, H.; Zhao, Z.S.; Lim, L. A brain serine/threonine protein kinase activated by Cdc42 and Rac1. Nature 1994, 367, 40-46. [CrossRef]

7. Stupack, D.G.; Cho, S.Y.; Klemke, R.L. Molecular signaling mechanisms of cell migration and invasion. Immunol. Res. 2000, 21, 83-88. [CrossRef]

8. Ding, Y.; Milosavljevic, T.; Alahari, S.K. Nischarin inhibits LIM kinase to regulate cofilin phosphorylation and cell invasion. Mol. Cell. Biol. 2008, 28, 3742-3756. [CrossRef]

9. Bokoch, G.M. Biology of the p21-activated kinases. Annu. Rev. Biochem. 2003, 72, 743-781. [CrossRef]

10. Chew, T.L.; Masaracchia, R.A.; Goeckeler, Z.M.; Wysolmerski, R.B. Phosphorylation of non-muscle myosin II regulatory light chain by p21-activated kinase (gamma-PAK). J. Muscle Res. Cell Motil. 1998, 19, 839-854. [CrossRef]

11. Daniels, R.H.; Bokoch, G.M. p21-activated protein kinase: A crucial component of morphological signaling? Trends Biochem. Sci. 1999, 24, 350-355. [CrossRef]

12. Edwards, D.C.; Sanders, L.C.; Bokoch, G.M.; Gill, G.N. Activation of LIM-kinase by Pak1 couples Rac/Cdc42 GTPase signalling to actin cytoskeletal dynamics. Nat. Cell. Biol. 1999, 1, 253-259. [CrossRef]

13. Vadlamudi, R.K.; Kumar, R. P21-activated kinases in human cancer. Cancer Metastasis Rev. 2003, 22, 385-393. [CrossRef] [PubMed]

14. Bamburg, J.R.; McGough, A.; Ono, S. Putting a new twist on actin: ADF/cofilins modulate actin dynamics. Trends Cell Biol. 1999, 9, 364-370. [CrossRef] 
15. Huynh, N.; Liu, K.H.; Baldwin, G.S.; He, H. P21-activated kinase 1 stimulates colon cancer cell growth and migration/invasion via ERK- and AKT-dependent pathways. Biochim. Biophys. Acta 2010, 1803, 1106-1113. [CrossRef] [PubMed]

16. Wu, D.-W.; Wu, T.-C.; Chen, C.-Y.; Lee, H. PAK1 Is a Novel Therapeutic Target in Tyrosine Kinase Inhibitor-Resistant Lung Adenocarcinoma Activated by the PI3K/AKT Signaling Regardless of EGFR Mutation. Clin. Cancer Res. 2016, 22, 5370-5382. [CrossRef]

17. Kessel, K.A.; Lettner, S.; Kessel, C.; Bier, H.; Biedermann, T.; Friess, H.; Herrschbach, P.; Gschwend, J.E.; Meyer, B.; Peschel, C.J Use of complementary and alternative medicine (CAM) as part of the oncological treatment: Survey about Patients' attitude towards CAM in a university-based oncology Center in Germany. PLoS ONE 2016, 11, e0165801.

18. Zaid, H.; Silbermann, M.; Amash, A.; Gincel, D.; Abdel-Sattar, E.; Sarikahya, N.B. Medicinal plants and natural active compounds for cancer chemoprevention/chemotherapy. Evid. Based Complement Alternat. Med. 2017, 2017, 7952417. [CrossRef]

19. Shizhen, L. Bencao Gangmu; People's Medical Publishing House Co., LTD: Beijing, China, 1975.

20. Kroemer, G.; Reed, J.C. Mitochondrial control of cell death. Nat. Med. 2000, 6, 513-519. [CrossRef] [PubMed]

21. Cain, K. Chemical-induced apoptosis: Formation of the Apaf-1 apoptosome. Drug Metab. Rev. 2003, 35, 337-363. [CrossRef]

22. Cohen, G.M. Caspases: The executioners of apoptosis. Biochem. J. 1997, 326 Pt 1, 1-16. [CrossRef]

23. Fischer, U.; Schulze-Osthoff, K. Apoptosis-based therapies and drug targets. Cell Death Differ. 2005, 12 (Suppl. 1), $942-961$. [CrossRef] [PubMed]

24. King, H.; Nicholas, N.S.; Wells, C.M. Role of p-21-activated kinases in cancer progression. Int. Rev. Cell Mol. Biol. 2014, 309, 347-387. [CrossRef] [PubMed]

25. Arnold, J.J.; McIntosh, E.D.; Martin, F.J.; Menser, M.A. A fifty-year follow-up of ocular defects in congenital rubella: Late ocular manifestations. Aust. N. Z. J. Ophthalmol. 1994, 22, 1-6. [CrossRef]

26. Goc, A.; Al-Azayzih, A.; Abdalla, M.; Al-Husein, B.; Kavuri, S.; Lee, J.; Moses, K.; Somanath, P.R. P21 Activated kinase-1 (Pak1) Promotes Prostate Tumor Growth and Microinvasion via Inhibition of Transforming Growth Factor $\beta$ Expression and Enhanced Matrix Metalloproteinase 9 Secretion. J. Biol. Chem. 2013, 288, 3025-3035. [CrossRef] [PubMed]

27. Abdel-Magid, A.F. PAK1: A Therapeutic Target for Cancer Treatment. ACS Med. Chem. Lett. 2013, 4, 431-432. [CrossRef]

28. Chow, H.Y.; Dong, B.; Valencia, C.A.; Zeng, C.T.; Koch, J.N.; Prudnikova, T.Y.; Chernoff, J. Group I Paks are essential for epithelialmesenchymal transition in an Apc-driven model of colorectal cancer. Nat. Commun. 2018, 9, 3473. [CrossRef]

29. Bae, K.; Kim, E.; Choi, J.J.; Kim, M.K.; Yoo, H.S. The effectiveness of anticancer traditional Korean medicine treatment on the survival in patients with lung, breast, gastric, colorectal, hepatic, uterine, or ovarian cancer: A prospective cohort study protocol. Medicine 2018, 97, e12444. [CrossRef]

30. Ye, L.; Jia, Y.; Ji, K.E.; Sanders, A.J.; Xue, K.; Ji, J.; Mason, M.D.; Jiang, W.G. Traditional Chinese medicine in the prevention and treatment of cancer and cancer metastasis. Oncol. Lett. 2015, 10, 1240-1250. [CrossRef]

31. Lee, H.-Y.; Kim, J.-E.; Kim, M.; Kim, J.-H. A review of traditional Korean medical treatment for cancer-related cognitive impairment. J. Korean Med. 2016, 37, 74-86. [CrossRef]

32. Xiang, Y.N.; Cuo, Z.M.; Zhu, P.F.; Chen, J.; Huang, Y.Y. Traditional Chinese medicine as a cancer treatment: Modern perspectives of ancient but advanced science. Cancer Med. 2019, 8, 1958-1975. [CrossRef]

33. Gong, W.Y.; Wu, J.F.; Liu, B.J.; Zhang, H.Y.; Cao, Y.X.; Sun, J.; Lv, Y.B.; Wu, X.; Dong, J.C. Flavonoid components in Scutellaria baicalensis inhibit nicotine-induced proliferation, metastasis and lung cancer-associated inflammation in vitro. Int. J. Oncol. 2014, 44, 1561-1570. [CrossRef] [PubMed]

34. Zhao, Y.; Yao, J.; Wu, X.P.; Zhao, L.; Zhou, Y.X.; Zhang, Y.; You, Q.D.; Guo, Q.L.; Lu, N. Wogonin suppresses human alveolar adenocarcinoma cell A549 migration in inflammatory microenvironment by modulating the IL-6/STAT3 signaling pathway. Mol. Carcinog. 2015, 54 (Suppl. 1), E81-E93. [CrossRef] [PubMed]

35. Lu, C.; Wang, H.; Chen, S.; Yang, R.; Li, H.; Zhang, G. Baicalein inhibits cell growth and increases cisplatin sensitivity of A549 and H460 cells via miR-424-3p and targeting PTEN/PI3K/Akt pathway. J. Cell. Mol. Med. 2018, 22, 2478-2487. [CrossRef]

36. Cho, S.M.; Lee, E.O.; Kim, S.H.; Lee, H.J. Essential oil of Pinus koraiensis inhibits cell proliferation and migration via inhibition of p21-activated kinase 1 pathway in HCT116 colorectal cancer cells. BMC Complement. Altern. Med. 2014, 14, 275. [CrossRef] [PubMed]

37. Menges, C.W.; Sementino, E.; Talarchek, J.; Xu, J.F.; Chernoff, J.; Peterson, J.R.; Testa, J.R. Group I p21-Activated Kinases (PAKs) Promote Tumor Cell Proliferation and Survival through the AKT1 and Raf-MAPK Pathways. Mol. Cancer Res. 2012, 10, $1178-1188$. [CrossRef]

38. Rane, C.K.; Minden, A. P21 activated kinase signaling in cancer. Proc. Semin. Cancer Biol. 2019, 54, 40-49. [CrossRef]

39. Thullberg, M.; Gad, A.; Beeser, A.; Chernoff, J.; Stromblad, S. The kinase-inhibitory domain of p21-activated kinase 1 (PAK1) inhibits cell cycle progression independent of PAK1 kinase activity. Oncogene 2007, 26, 1820-1828. [CrossRef]

40. Ong, C.C.; Jubb, A.M.; Haverty, P.M.; Zhou, W.; Tran, V.; Truong, T.; Turley, H.; O’Brien, T.; Vucic, D.; Harris, A.L.; et al. Targeting p21-activated kinase 1 (PAK1) to induce apoptosis of tumor cells. Proc. Natl. Acad. Sci. USA 2011, 108, 7177-7182. [CrossRef]

41. Qian, Y.; Wu, X.; Wang, H.X.; Hou, G.W.; Han, X.; Song, W. PAK1 silencing is synthetic lethal with CDK4/6 inhibition in gastric cancer cells via regulating PDK1 expression. Hum. Cell 2020, 33, 377-385. [CrossRef]

42. Li, W.; Ni, Q.; Zhao, Z.; Zhang, C. Inhibitory effects of seahorse treat S180 entity tumor in mic. Med. Pharmacacetical J. 1998, $20,6-7$.

43. Aimin, Z. Pharmacologic Researches on Ethanol Extracts from Hippocampus. J. Chin. Pharm. Aff. 2005, 1, 23-25. 
44. Meng, X.; Xu, D.; Mei, X.; Xu, S.; Lv, J.; Li, B.J. Research on Hippocampus capsule therapy of experimental benign prostatic hyperplasia. Chin. Pharm. J. 2005, 40, 190-193.

45. Xu, D.H.; Wang, L.H.; Mei, X.T.; Li, B.J.; Lv, J.L.; Xu, S.B. Protective effects of seahorse extracts in a rat castration and testosteroneinduced benign prostatic hyperplasia model and mouse oligospermatism model. Environ. Toxicol. Pharmacol. 2014, 37, 679-688. [CrossRef]

46. Cha, T.L.; Qiu, L.; Chen, C.T.; Wen, Y.; Hung, M.C. Emodin down-regulates androgen receptor and inhibits prostate cancer cell growth. Cancer Res. 2005, 65, 2287-2295. [CrossRef] [PubMed]

47. Yu, C.X.; Zhang, X.Q.; Kang, L.D.; Zhang, P.J.; Chen, W.W.; Liu, W.W.; Liu, Q.W.; Zhang, J.Y. Emodin induces apoptosis in human prostate cancer cell LNCaP. Asian J. Androl. 2008, 10, 625-634. [CrossRef]

48. Huang, Q.; Shen, H.M.; Ong, C.N. Emodin inhibits tumor cell migration through suppression of the phosphatidylinositol 3-kinase-Cdc42/Rac1 pathway. Cell Mol. Life Sci. 2005, 62, 1167-1175. [CrossRef]

49. Yang, C.S.; Wang, H. Cancer Preventive Activities of Tea Catechins. Molecules 2016, 21, 1679. [CrossRef]

50. Dou, Q.P. Molecular mechanisms of green tea polyphenols. Nutr. Cancer 2009, 61, 827-835. [CrossRef]

51. Tsai, Y.J.; Chen, B.H. Preparation of catechin extracts and nanoemulsions from green tea leaf waste and their inhibition effect on prostate cancer cell PC-3. Int. J. Nanomed. 2016, 11, 1907-1926. [CrossRef]

52. Xiang, L.P.; Wang, A.; Ye, J.H.; Zheng, X.Q.; Polito, C.A.; Lu, J.L.; Li, Q.S.; Liang, Y.R. Suppressive Effects of Tea Catechins on Breast Cancer. Nutrients 2016, 8, 458. [CrossRef]

53. Rogovskii, V.S.; Popov, S.V.; Sturov, N.V.; Shimanovskii, N.L. The Possibility of Preventive and Therapeutic Use of Green Tea Catechins in Prostate Cancer. Anti-Cancer Agents Med. Chem. 2019, 19, 1223-1231. [CrossRef] [PubMed]

54. Erdogan, S.; Doganlar, O.; Doganlar, Z.B.; Turkekul, K. Naringin sensitizes human prostate cancer cells to paclitaxel therapy. Prostate Int. 2018, 6, 126-135. [CrossRef]

55. Yim, D.; Singh, R.P.; Agarwal, C.; Lee, S.; Chi, H.; Agarwal, R. A novel anticancer agent, decursin, induces G1 arrest and apoptosis in human prostate carcinoma cells. Cancer Res. 2005, 65, 1035-1044.

56. Jiang, C.; Lee, H.J.; Li, G.X.; Guo, J.M.; Malewicz, B.; Zhao, Y.; Lee, E.O.; Lee, H.J.; Lee, J.H.; Kim, M.S.; et al. Potent antiandrogen and androgen receptor activities of an Angelica gigas-containing herbal formulation: Identification of decursin as a novel and active compound with implications for prevention and treatment of prostate cancer. Cancer Res. 2006, 66, 453-463. [CrossRef]

57. Lu, J.; Kim, S.H.; Jiang, C.; Lee, H.; Guo, J. Oriental herbs as a source of novel anti-androgen and prostate cancer chemopreventive agents. Acta Pharmacol. Sin. 2007, 28, 1365-1372. [CrossRef]

58. Song, G.-Y.; Lee, J.-H.; Cho, M.; Park, B.-S.; Kim, D.-E.; Oh, S. Decursin suppresses human androgen-independent PC3 prostate cancer cell proliferation by promoting the degradation of $\beta$-catenin. Mol. Pharmacol. 2007, 72, 1599-1606. [CrossRef] [PubMed]

59. Lee, H.J.; Lee, H.J.; Lee, E.O.; Lee, J.H.; Lee, K.S.; Kim, K.H.; Kim, S.H.; Lu, J. In vivo anti-cancer activity of Korean Angelica gigas and its major pyranocoumarin decursin. Am. J. Chin. Med. 2009, 37, 127-142. [CrossRef]

60. Wartenberg, M.; Ling, F.C.; Müschen, M.; Klein, F.; Acker, H.; Gassmann, M.; Petrat, K.; Pütz, V.; Hescheler, J.; Sauer, H. Regulation of the multidrug resistance transporter P-glycoprotein in multicellular tumor spheroids by hypoxia-inducible factor- 1 and reactive oxygen species. FASEB J. 2003, 17, 1-22. [CrossRef]

61. Baker, B.M.; Chen, C.S. Deconstructing the third dimension-How 3D culture microenvironments alter cellular cues. J. Cell Sci. 2012, 125, 3015-3024. [CrossRef]

62. Davies, G.; Jiang, W.G.; Mason, M.D. Cell-cell adhesion molecules and signaling intermediates and their role in the invasive potential of prostate cancer cells. J. Urol. 2000, 163, 985-992. [CrossRef]

63. Kasinskas, R.W.; Venkatasubramanian, R.; Forbes, N.S. Rapid uptake of glucose and lactate, and not hypoxia, induces apoptosis in three-dimensional tumor tissue culture. Integr. Biol. 2014, 6, 399-410. [CrossRef]

64. Wenzel, C.; Riefke, B.; Grundemann, S.; Krebs, A.; Christian, S.; Prinz, F.; Osterland, M.; Golfier, S.; Rase, S.; Ansari, N.; et al. 3D high-content screening for the identification of compounds that target cells in dormant tumor spheroid regions. Exp. Cell Res. 2014, 323, 131-143. [CrossRef] [PubMed]

65. Fomin, M.A.; Dmitriev, R.I.; Jenkins, J.; Papkovsky, D.B.; Heindl, D.; Konig, B. Two-Acceptor Cyanine-Based Fluorescent Indicator for NAD(P)H in Tumor Cell Models. ACS Sens. 2016, 1, 702-709. [CrossRef] 